TEME, г. XLI, бр. 1, јануар-март 2017, стр. 293-295

Приказ дела

DOI: $10.22190 /$ TEME1701293T

Примљено: 19. 05. 2016.

Одобрено за штампу: 17. 01. 2017.

\title{
ПРИКАЗ КЊИГЕ ПРОФ. ДР ДАНИЛА Ж. МАРКОВИЋА СОЦИЈАЛНА ЕКОЛОГИЈА
}

\section{Саво Трифуновић}

Универзитет у Крагујевцу, Факултет за машинство и грађевинарство у Краљеву, Србија

trifunovic.s@mfkv.kg.ac.rs

Данас је код нас све присутнија пракса причања (по)велике и лепе „еколошке приче” у којој је све мање екологије, односно у којој (скоро да) нема екологије, а (скоро да) нема ни (озбиљне) приче!

Страховладна је и тенденција пораста броја „великих научника” (и) код нас! То су они „напокон откривени” таленти што часком, док дланом о длан, напишу - књигу! Пишу они наврат-нанос и тзв. књиге за народ, па и „књижекање”, „књижурде”. Ми овде новаковићевски питамо „Quid nunc?” и одмах упућујемо на тражење излаза и у науци социјалној екологији.

Некако у време кад смо већ били помислили да је проф. др Данило Ж. Марковић, што се објављивања књига тиче, помало страхињбановски „зачамао”, он нас је поново обрадовао. Наиме, из штампе је изашла, сада већ с правом можемо рећи, знаменита књига тог нашег научника првога реда под насловом Социјална екологија. То шесто издање на српском језику објавио је наш реномирани издавач „Завод за уџбенике” (2015) из Београда. Штампана је у тиражу од 500 примерака.

Књига има 504 странице. Писана је прелепим ћириличним писмом. На почетку она има, како и приличи, „Предговор” и „Увод”. Проф. др Данило Ж. Марковић је структуру књиге поделио у десет глава, које чине логичан и смислен, скоро питагорејски низ. На крају књиге, аутор нам је изложио списак „Одабране литературе”.

Придржавајући се методолошког начела „од општег ка посебном”, а после „од посебног ка појединачном”, наш чувени професор је у првој глави ове књиге, под насловом „Екологија и савремени еколошки проблеми”, зналачки изложио „Предмет и поделу екологије”, затим „Настанак и развој екологије”, те „Основне категорије екологије”.

Господин аутор у другој глави, којој је наслов „Предмет социјалне екологије и њен однос према другим наукама”, изузетно компетентно конкретизује предметну одређеност социјалне екологије.

У трећој глави, односно оној под насловом „Метод социјалне екологије”, поштовани аутор минуциозно указује благодарном читаоцу на „Тешкоће у изграђивању метода социјалне екологије”, које је (тешкоће), рецимо, још Аристотел у својој Метафизици с правом назвао „прастаре тешкоће”. 
За све наше социјалне екологе и оне који се занимају за проблеме социјалне екологије, проф. др Данило Ж. Марковић је у три поменуте главе књиге завршио (и зато - Хвала!) један ђаволски тежак посао, а нама на радост! Ми знамо да нема науке без њеног прецизног одређења предмета истраживања, без „разграничења” и без „њеног” метода, односно „њених” метода, и методолошког инструментаријума, а којима се „она користи” (и ваља да се користи) при истраживању истине о предмету истраживања, а све то у контексту њене научне, односно предметне одређености и усмерености. О каквом се прецизном, а свеобухватном захвату ради, показаћемо навођењем дефиниције науке социјалне екологије професора Данила Ж. Марковића. Он сматра „да је могуће социјалну екологију одредити као посебну социологију која за предмет свог проучавања има специфичне везе између човека и његове животне средине, истражујући (у контексту опште концептуализације универзума уједињеног са специфичним условима живота) утицај животне средине као укупности природних и друштвених чинилаца на човека, као и утицај човека на његову животну средину са становишта њеног очувања као оквира човековог живота, као природно-друштвеног бића" (стр. 74).

У четвртој глави аутор обрађује „Човекову средину”, у петој „Еколошку кризу и могућности њеног решавања”, у шестој „Заштиту човекове животне средине".

Седма глава посвећена је „Еколошкој култури и еколошком образовању”, осма „Еколошкој политици”, девета „Еколошким покретима и партијама” и десета - „Социјалној екологији и друштвеном развоју”.

Након тога следи списак „Одабране литературе” и - крај књиге. Остаде иза нас пола хиљаде и четири странице.

Приводећи крају овај приказ, желимо истаћи, јер тако сматрамо, да је најмање шест остварених циљева ове лепе и квалитетне књиге, а они су редом: да подучи, да буде, да усмери, да иницира, да просветли, да појасни, да облагороди.

Прво, да подучи студенте и њихове професоре у широкој области социјалне екологије.

Друго, да буде инспирација и део теоријске подлоге научноистраживачких пројеката у области социјалне екологије, односно и да допринесе промишљању нове позиције и промењивих слика човека (changing images of the man) у савременом друштву.

Tpeћ, да усмери ка еколошко-етичким квалитетима и људским сврхама (срећа, доброта, пријатност, смањење људских патњи), социјалној правди, које се мере увек личном и најиндивидуалнијом мером коју ми називамо задовољство, а не само, једино и a priori да су усмерени ка циљевима који су мерљиви и који се могу квантификовати, а који се мере разликама између тзв. инпута и аутпута, односно мером коју називамо исплативост и профит (при инвестирању „зелембаћа” - „у зелено”, „у еколошко”).

Четврто, да отпочне плодну расправу поводом социјално-еколошких идеја (помака). Подоста је велики радник и генијални човек проф. др Данило Ж. Марковић уложио труда у настојању да ублажи једно велико „проклетство” наставничке професије, а то је да искључиво тумачи оно што су други (о)смислили, остварили и уобличили. 
Пето, да „просветли” проблеме, не само нашој широј јавности, којој су то већ свакодневни проблеми, него и нашој стручној (управљачкој) јавности, на свим нивоима где „царује” - да не зацари, па и прецари, јер зацаривања и прецаривања нема без декаденције и моралног разврата према животној средини. А управо та и таква наша јавност усмерава и одлучује о даљим правцима нашег технолошког, а то значи и друштвеног, одрживог развоја - у променама.

Шесто, да појасни и објасни неке проблеме с којима се и наше друштво сусреће, а од којих су многи стална тема нашег ризичног, учећег, али и друштва које је још увек на раскрсници - ка ваљаном, добром, друштву. Еколошки проблеми о којима је реч у књизи и с којима се сусреће српско друштво, у значајној су мери проблеми које су друштва развијених демократија већ увелико доживела и проживљавају, па се и данас рву с њима - мада су већ добрано закорачила и у тзв. постинформатичко друштво. Добар оријентир дао нам је аутор у овој књизи. Остало зависи од нас и нашег знања -које мора бити мудрост учења и на туђим грешкама, а не дилетантство што „пуним рукама дарује неснесена јаја” (Ернст Блох), као ни „преученост”, недоученост која „мало види, а велико превиђа” (Аристотел).

У овој књизи, виспрени ће, надамо се, пронаћи виспрено. Мудри ће пронаћи мудро. Упорни ће пронаћи одговорено на питано. Сигурни смо, јер знамо, да ће ова књига имати још подоста издања. Зато аутору, односно многознанцу посебнога кова, чувеном професору, генијалном човеку, знањем - силном, а човекољубљем и уљудношћу - великом проф. др Данилу Ж. Марковићу, издавачу и свим читаоцима - срећна књига. Поштованом професору Данилу нека је још и - добро здравље! 